\title{
Preparation and Mechanical Properties of Bean-curd Refuse/Biodegradable Polymer composites
}

\author{
○学 長岡洋史（秋田県立大院） 正 邱 建輝（秋田県立大） \\ 正 中山 昇（秋田県立大）正 熊沢鉄雄（秋田県立大） \\ 工藤 素（秋田産技センター）＼cjkstart鎌田＼cjkstart悟（秋田産技センター）
}

Hiroshi NAGAOKA, Graduate School of Akita Prefectural University,

84-4 Ebinoguchi, Tsuchiya, Yurihonjyo, Akita

Jianhui QIU, Noboru NAKAYAMA, Tetsuo KUMAZAWA, Akita Prefectural University

Makoto KUDO, Satoru KAMATA, Akita Prefectural R and D Center

\section{1. 緒言}

近年, 資源の枯渴や地球環境問題等が深刻化されている. 高分子工業においても環境負荷が少なく，廃棄可能な生分 解性樹脂に関する研究も盛んに行われている ${ }^{1)}$ 。しかし， 製造コストが高く，普及にはまだ至っていない，

また, 食品業界においても食品廃棄物の問題がある ${ }^{2), 3)}$. 豆腐製造時の副産物であるおからは産業廃育物として位置 づけられており，年間で約 70 万トン産出されている。 ま た, 平成 13 年に食品リサイクル法が施行され, 今年から 食品関連事業者は食品廃棄物を $20 \%$ 削減させるという目 標値を定めている. そのため, 最近, おからの利用に関す る研究が盛んに行われている ${ }^{4)}$. しかし，おから特有の日 持ちの悪さや臭い等の問題点があり, 乾燥処理や脱脂処理 を行う必要がある。

本研究では生分解性樹脂の普及と, おからの有効利用を 考え, 生分解性樹脂とおからの複合材料を作製し, おから を脱脂処理することによる成形品の外観や材料強度に及ぼ す影響を調べた。

\section{2. 材料及び実験方法}

2.1 材料

母材には生分解性樹脂（ダイセル化学工業（株）製 セル グリーン PH7）を用いた. セルグリーンを使用した理由と しては，おからと複合化させたときに，成形温度があまり 高すぎると，おから中に含まれる脂質が酸化してしまい， 悪臭が発生してしまうことから, 成形温度の低い生分解性 樹脂を選んだ.

おからは，Table1 に示すように水分を $80 \%$ 以上含み，腐 敗しやすいため, 乾燥機中で約 $300^{\circ} \mathrm{C}$ の熱風により乾燥を 行った. その後, 乾燥させたおからは粒子が大きいため, 生分解性樹脂と均一に混ざり合うように，粉砕処理を行っ た. さらに，おからの成分中に含まれる脂質には，大豆特 有の臭いの原因となる不飽和脂肪酸等が含まれ, 高温成形 で使用すると臭いが発生するため, 溶剤を用いて脱脂処理 を行った. 脱脂の方法は, 粉砕したおからと溶剤を $1350 \mathrm{~g}$ : 3L の割合でビーカーの中に入れ，靦拌機で擋䢁を行った. 溶剂は，エチルアルコール（純度 $99.5 \%$ ），アセトンの 2 種類を用いて脱脂処理に与える影響を比較した。またお から粉末および抽出物質の測定には, フーリエ変換型赤外

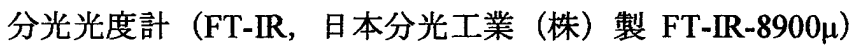
により測定した.
Table1 Element of Bean-curd Refuse

\begin{tabular}{|c|c|c|c|c|c|}
\hline 水分 & たんぱく質 & 脂質 & 水化物 & 灰分 & カルシウム \\
\hline 83.7 & 3.2 & 2.1 & 9.9 & 0.7 & 0.16 \\
\hline
\end{tabular}

\section{2 試験片の成形}

小型混練機（クリエイトプラスチック株式会社製 CH-1100）に生分解性樹脂のペレットとおからの粉末を重 量組成比 (セルグリーン: おから粉末 $=100: 0,90: 10,70: 30$, 50:50）でペレットを作製し，その後，作製したペレットを 再度混練機に投入し，金型を設置して，JIS1(1/2)号形ダン ベル型試験片を作製した. 射出成形条件は, 射出温度 $\mathrm{T}$ ： $130^{\circ} \mathrm{C}$, 射出速度 $\mathrm{V}_{\mathrm{i}}: 1 \mathrm{~mm} / \mathrm{s}$, 金型温度 $\mathrm{T}_{\mathrm{C}}: 60^{\circ} \mathrm{C}$ とした。 しかし, 脱脂おからを $50 \mathrm{wt} \%$ 添加したブレンド材は流動性 が悪く, 成形できなかった.

\section{3 引張試験}

作製したダンベル型試験片を用いて，引張試験機 （INSTRON（株）製 Series 3360）で引張試験を行い，引 張強さ $(\sigma)$ 及び破断歪み $(\varepsilon)$ を求めた。試験条件は引 張速度 $10 \mathrm{~mm} / \mathrm{min}$, 室温 $23 \pm 1^{\circ} \mathrm{C}$ である.

\section{4 破断面の観察}

ダンベル型試験片を冷凍破断させ，破断面を走査型電子 顕微鏡 S-4300 型（日立製作所（株）製）を用いて観察した.

\section{3. 実験結果及び考察}

\section{$3.1 お か ら の$ 脱脂処理}

Fig.1 に，無処理のおから，及びエチルアルコール（純度 99.5\%）又はアセトンを用いて脱脂処理を行ったおからの 赤外吸収スペクトルの波形を示す．脂質の分子中にはカル ボキシル基を有するカルボン酸を含んでおり，無処理のお からでは $1725 \mathrm{~cm}^{-1}$ 付近にカルボン酸中の $\mathrm{C}=\mathrm{O}$ の伸縮振動 の吸収が認められた。しかし，各溶剤で脱脂処理を行った 結果, $1725 \mathrm{~cm}^{-1}$ 付近に認められる $\mathrm{C}=\mathrm{O}$ の伸縮振動による吸 収ピークが低くなり，脂質が除去されていることがわかる. また，溶凨の種類の影響を比較すると，アセトンで脱脂処 理を行ったおからの方が，エタノールで脱脂处理を行うよ りも, $1725 \mathrm{~cm}^{-1}$ 付近に認められる $\mathrm{C}=0$ の伸縮振動による吸 収ピークが低くなり，より脂質が除去されていることがわ かる. しかし，アセトンの使用は環境にあまり良くないこ とから, 以後, 本実験ではエチルアルコールで脱脂処理を 行ったおからを使用することとする. 
また, Fig.2には, 無処理のおからとエチルアルコールで 脱脂処理を行った脱脂おからの SEM 写真を示す。無処理 のおからの粒度は約 $30 \mu \mathrm{m}$ であったのが， 2 次粒子化して おり約 $200 \mu \mathrm{m}$ 程の粒子の塊も確認された。しかし，脱脂 処理を行うことによって，おからの中に含まれる脂質が除 去されたため，脂質によるおからの 2 次粒子化が起こらな くなり粒子は均一に約 $30 \mu \mathrm{m}$ であった.

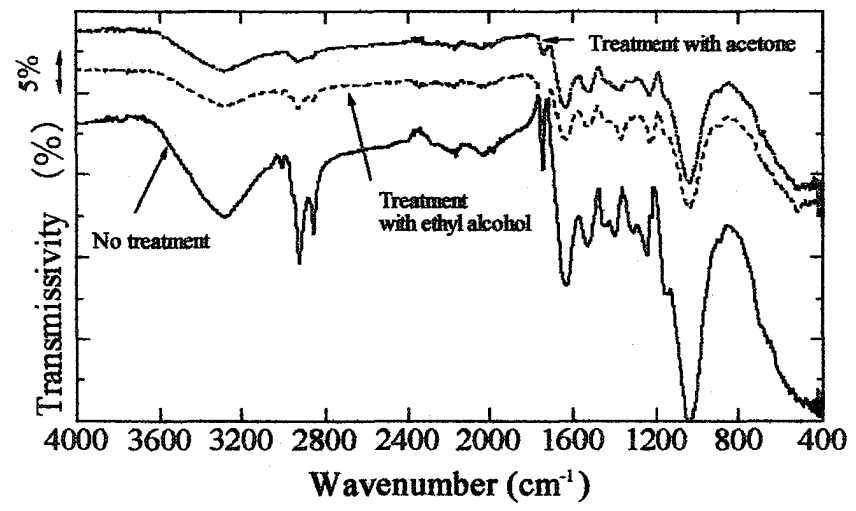

Fig.1 Effect of kind of solvent on Treatment of removing fat

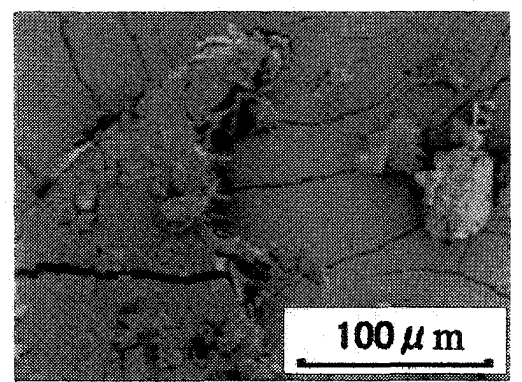

a) No treatment

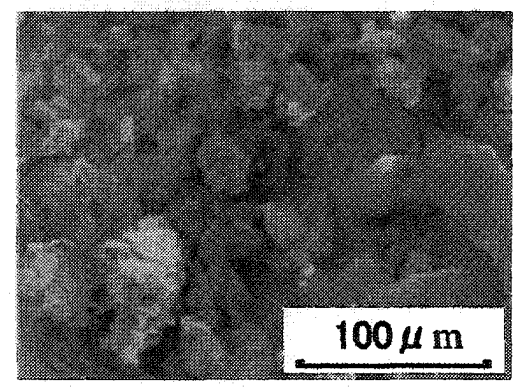

b) Treatment with ethyl alcohol

Fig.2 SEM photographs of Bean-curd Refuse

3.2 脱脂処理及びおからの添加量による引張特性の変化

Fig.3には，引張強さおよび破断歪みに及ぼす脱脂処理の 影響を示す。おからの脱脂処理の有無にかかわらず，おか らを $10 \mathrm{wt}$ ％添加した場合，破断歪みは急激に滅少し，母 材の破断歪みが 1300\%だったのに対し, 約 300\%となった。 引張強さは，母材が約 16MPa であったが，エタノールで脱

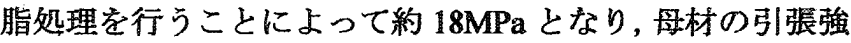
さよりも約 $12 \%$ 上昇した．また，脱脂処理の影響を比較す ると，脱脂処理を行うことにより，無処理のおからを添加 した場合よりも，全体的に強度が上昇した。しかし，破断 歪みについては，脱脂処理をすることで全体的に堿少して いる.
おからを脱脂処理することにより複合材料の强度が上昇 した要因を謂べるために，無処理のおから又は脱脂おから を 10wt,\%添加した複合材料の SEM 䚁察を行った. その 結果，おから中の脂質を除去することによって複合材料内 部で，おから粒子の 2 次粒子化がなくなり，おから粒子が ブレンド材内部でよく分散し，そのため強度が上昇したと 考えられる．また，破断歪みが減少した要因としては，脂 質を除去したことによって，内部で樹脂とおから粒子の間 の滑りが覀くなったためであると考えられる.

また，ブレンド材成形品の外観や臭いは，おからを脱脂 処理することで，おから中に含まれる脂質の酸化が抑えら れ，変色及び鼻いも抑えることができた，しかし，おから の添加量が 50wt,\%の場合には，おからの添加量が多かっ たため, 成形品は焦げ茶色に変色した。

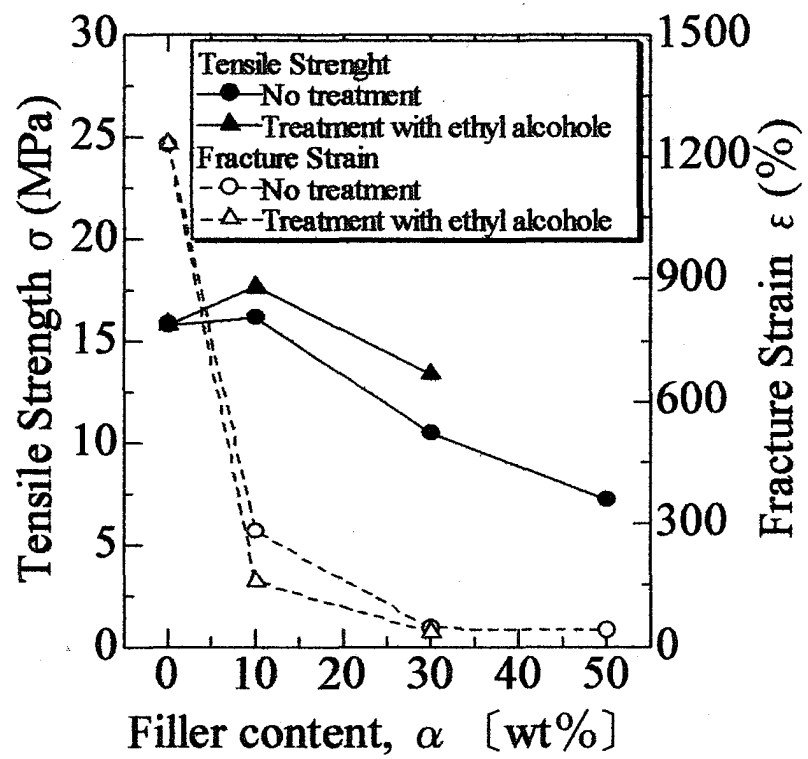

Fig.3 Effect of Treatment of removing fat on Tensile Strength and Fracture Strain

\section{4. 結言}

本研究は，生分解性樹脂とおからの複合材料を作製し， おからを脱脂処理することによる成形品の外観や材料強度 に及ぼす影響を調べた. その結果, 以下のことがわかった。

1）おからを脱脂処理することによって，粒子を細かくす ることができた. 成形品の外䅐や臭いについては，大 豆特有の臭いをある程度取除くことができ，更に成形 品の変色も抑えられた。

2）生分解性樹脂とおからをブレンドする場合に，おから を脱脂処理することで，おからの添加量が 10wt,\%の 場合，母材の引張強さより約 $12 \%$ 上昇した.

参考文献

（1）山田和信：高分子論文集 59，〔12]，p.760 (2002)

（2）清水直人：農業機棫学会誌 66, [3]，p.8 (2004)

（3）渡辺篤二 : 研究ジャーナル 17， [8]，p.6（1994）

（4）鈔田栄基：食品工業 46，[6]，p.53（2003） 